\title{
DEVELOPMENT AND RESEARCH OF THE WELL PLUGGING MICROCEMENT-BASED COMPOSITION TO LIMIT AND ELIMINATE THE WATER INFLOWS INTO OIL AND GAS WELLS
}

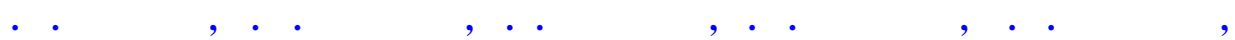
- оном рев

D. S. Leontiev, I. I. Kleschenko, A. V. Kustyshev, V. A. Dolgushin, M. D. Zavatski, A. A. Ponomarev

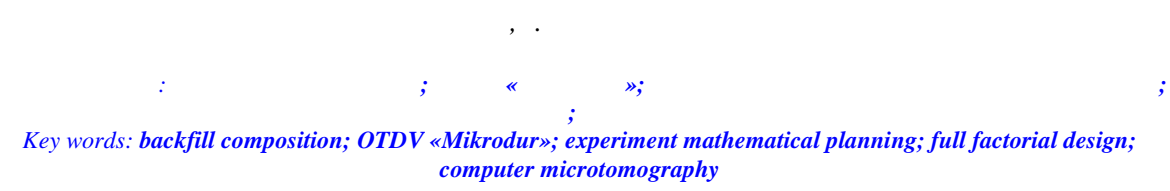

н стоящее время высок я обводненность добыв ющих скв жин является одной из основных проблем в нефтег зовой отр сли н шей стр ны. редний уровень обводненности в оссии (в том числе и в п дной ибири) возр ст ет почти н $2 \%$ в год и в н стоящий период превысил отметку $80 \%$.

резмерно высокий уровень обводненности ведет к снижению рент бельности добычи углеводородов и увеличению их себестоимостей, возр ст ющим з тр т м н утилиз цию попутно добыв емой воды, с мое гл вное - сниж ет дебит скв жин и конечную нефтег зоотд чу продуктивных пл стов. громное количество добыв ющих скв жин приходится ликвидиров ть по причине преждевременного прогрессирующего обводнения $[1,2]$.

к известно, т кие геологические и технические особенности скв жин, к к н личие подошвенной (или з контурной) воды, высокопрониц емых пропл стков, нек чественное цементиров ние и коррозия обс дной колонны и др., способствуют ускоренному процессу обводнения $[1,2]$.

сегодняшний день в мире $\mathrm{p}$ зр бот но и з п тентов но дост точно большое количество сост вов и технологий по огр ничению и ликвид ции приток пл стовых вод, одн ко до конц 3 д ч по изоляции водопритоков в нефтяные и г зовые скв жины не решен .

к пр вило, при проведении водоизоляционных р бот ( ) к т мпон жным сост в м предъявляются следующие требов ния [3, 4]:

- сост в должен обл д ть хорошей текучестью и сохр нять это свойство в процессе 3 к чив ния и прод влив ния в пл ст;

- $\quad$ сост в должен обл д ть миним льной водоотд чей с целью предотвр щения преждевременного з густев ния;

- $\quad$ сост в должен быть седимент льно ст бильным, чтобы в нем в состоянии покоя не обр зовыв лись к н лы, з полненные дисперсионной средой (водой);

- сопротивление неподвижного р створ фильтр ции пл стовых вод должно быть по величине не меньше избыточных пл стовых д влений, т кже переп д д влений между близко р сположенными прониц емыми горизонт ми в скв жине; 
- сроки схв тыв ния сост в должны легко регулиров ться, чтобы н ч ло схв тыв ния смеси превыш ло время всей опер ции по з к чив нию ее в пл ст н 10-15 минут;

- $\quad$ сост в должен быть устойчив к пл стовым вод м, иметь высокие зн чения структурно-мех нических свойств;

- $\quad$ сост в должен сохр нять ст бильность в пл стовых условиях во время проведения водоизоляционных р бот.

ля борьбы с обводнением скв жин необходимы т кие водоизолирующие м тери лы, которые способны проник ть в пористую среду изолируемых пл стов с 3 полнением всего пористого простр нств (в том числе низкопрониц емые коллекторы) с обр зов нием прочного водоизоляционного экр н, устойчивого к вымыв нию пл стовой водой. этом случ е при проведении кту льным является применение т мпон жного сост в н микроцементной основе.

о европейской кл ссифик ции микроцементом счит ется цемент с р змером ч стиц менее 20 мкм. к, известны м рки Spinor ( p нция), икроцемент ( инляндия), нтр цем ( , имени . . енделеев ). иболее р спростр ненной м ркой микроцемент является особо тонко дисперсное вяжущее ( ) « икродур» ( ерм ния, юккерхоф).

« икродур» - это минер льное гидр влическое вяжущее с особо тонким, постоянным и пл вно изменяющимся гр нулометрическим, т кже определенным и ст бильным химико-минер логическим сост вом. « икродур» изгот влив ется н основе обычного цементного сырья и состоит из портл ндцементного клинкер , доменного шл к , регуляторов твердения, минер льных доб вок и т. д. [5, 6].

зн ч льно композиционные м тери лы н основе « икродур» применялись для $[5,6,7]$ :

- усиления основ ний вновь строящихся и существующих зд ний и сооружений;

- устройств фунд ментов и других з глубленных конструкций р зного н зн чения из з крепленных грунтов;

- увеличения несущей способности св й и других опор большого ди метр путем созд ния под ними подушек из з крепленного грунт ;

- созд ния противофильтр ционных $з$ вес в к честве мероприятий по гидроизоляции подземных сооружений и конструкций.

ыпуск ется 4 м рки « икродур»: S, F, U, X, отлич ющихся по р змер м ч стиц (т блиц 1).

р ктеристики дисперсности суспензии

«кродур»

\begin{tabular}{|c|c|c|c|c|c|c|}
\hline \multirow{2}{*}{ рк } & \multicolumn{7}{|c|}{ оличество ч стиц с ди метром, \% } \\
\cline { 2 - 7 } & $<2$ мкм & $<4$ мкм & $<6$ мкм & $<9,5$ мкм & $<16$ мкм & $<24$ мкм \\
\hline $\mathrm{S}$ & 17 & 34 & 49 & 68 & 90 & 95 \\
\hline $\mathrm{F}$ & 19 & 45 & 60 & 80 & 95 & - \\
\hline $\mathrm{U}$ & 25 & 55 & 78 & 95 & - & - \\
\hline $\mathrm{X}$ & 45 & 80 & 95 & - & - & - \\
\hline
\end{tabular}

н стоящее время

« икродур» применяется при строительстве и эксплу т ции скв жин для огр ничения и ликвид ции водопритоков. примеру, профессором лещенко . . ( ) р зр бот н сост в, включ ющий поливиниловый спирт $(\quad)$, икродур «U» и гипохлорит к льция $\mathrm{Ca}(\mathrm{Cl})_{2}$ [8]. ник ровским . . и др. ( ) p зр бот н сост в, повыш ющий изоляцию подошвенных вод, состоящий из « икродур», сульф целл , этиленгликоля и воды [9]. г довой ..и др. ( нефти и г 3 имени . . убкин ) р зр бот н компонентный сост в из микроцемент

икро, понизителя фильтр ции « - ", 3 медлителя срок схв тыв ния « », еног сителя « есил-201» и воды [10].

мпон жные сост вы н основе « икродур» обл д ют рядом несомненных преимуществ, именно [5-7]:

- $\quad$ высокой способностью проник ть в трещины и поры р змером до 18 мкм и менее;

- седимент ционной устойчивостью (седимент ция суспензии од : « икродур» $=2: 1$ (по весу), не превыш ющей $5 \%$; 
- высокой прочностью сформиров нного т мпон жного к мня;

- существенным снижением коэффициент фильтр ции (с 1х10-4 до 1х10-7 м/с);

- снижением пок з телей водопрониц емости в результ те уплотнения в тысячу р $з$ и более;

- экологической безоп сностью;

- экономному р сходу м тери лов.

втор ми т кже р зр бот н т мпон жный сост в для ремонтно-изоляционных $\mathrm{p}$ бот в скв жин х н основе « икродур» м рки U, с доб влением полифункцион льного модифик тор и суперпл стифик тор .

об вки-модифик торы — веществ, доб вляемые в т мпон жные р створы с целью изменения одного (или нескольких) п р метр р створ при сохр нении неизменными ост льных п р метров. кие доб вки могут быть минер льного или техногенного происхождения, т кже р зличные продукты химических производств.

рименяемый полифункцион льный модифик тор предст вляет собой комплексный продукт н основе полиметиленн фт линсульфон тов н трия, ст билизирующих веществ с гидрофобизирующими компонент ми, обспечив ющий повышенные требов ния по прочности и долговечности получ ющегося цементного (микродурного) к мня. е содержит веществ, вызыв ющих коррозию оборудов ния.

одифик тор с гидрофобными свойств ми повыш ет пл стичность микродурного p створ без снижения его прочностных х p ктеристик сформиров нного т мпон жного К Мня.

рименяемый суперпл стифик тор предст вляет собой продукт н основе конденс ции н фт линсульфокислоты и форм льдегид, не содержит веществ, вызыв ющих коррозию, обл д ет ст билизирующим действием.

уперпл стифик тор позволяет получ ть при оптим льных дозировк х высокопл стифициров нные р створы при миним льном зн чении вод /цемент, позволяет зн чительно долго сохр нить подвижность и однородность р створов. овышенн я степень гидр т ции при меньшем / 3 счет диспергирующего действия позволяет достиг ть зн чительных зн чений прочности.

предл г емой втор ми р зр ботке н бор ингредиентов позволяет получить сост в для ремонтно-изоляционных р бот в скв жин х с высокими технологическими п р метр ми при изоляции воды в коллектор х любой прониц емости; при креплении сл босцементиров нных коллекторов в приз бойной зоне пл ст ; при ликвид ции 3 колонных перетоков; при ликвид ции притоков подошвенной воды (конус ); при ремонте эксплу т ционных колонн и др.

3 имное влияние компонентов друг н друг, их синергетическое действие в $\mathrm{p}$ 3p бот нном сост ве позволяет 3 счет ре кции и отверждения в пл стовых условиях обр зовыв ть прочный к мнеобр зный м тери л.

зр бот нный сост в можно применять для водоизоляции и крепления коллекторов любой прониц емости, поскольку он з к чив ется в пл ст в виде м ловязкого р створ , обр зов ние т мпон жного м тери л происходит непосредственно в пл сте, для н р щив ния цементного кольц в з колонном простр нстве скв жины, ремонт эксплу т ционных колонн и др.

рименение метод м тем тического пл ниров ния эксперимент с иелью обоснов ния оптим льной рецептуры водоизоляционной композиции н основе « икродур».

современном уровне р звития технологии и техники при пост новке исследов ний, н пр вленных н изучение сложных процессов, все большее зн чение приобрет ет пл ниров ние экспериментов - один из в жных р зделов м тем тической ст тистики [11].

т тистические методы пл ниров ния экспериментов основ тельно изменяют методику проведения р бот и позволяют ст вить опыты по некоторой $з$ р нее сост вленной схеме - одновременно изменять зн чения всех ф кторов, результ ты опытов р ссм трив ть совместно, их достоверность оценив ть метод ми м тем тической ст тистики. етоды пл ниров ния экспериментов - это р цион льн я орг низ ция исследов тельских р бот, сокр щение з тр т и средств их проведения. 
н ч л в пл не эксперимент величины влияющих ф кторов в рьируют в узких предел х. осле проведения эксперимент н лизируют результ ты и выбир ют м тем тическую модель, котор я д ет основу для нового эт п экспериментиров ния.

рименение методов пл ниров ния экспериментов, по ср внению с тр диционными метод ми, позволяет повысить эффективность н учных исследов ний в 2-10 р 3 [11]. ключение в пр ктику инженерных исследов ний методов р цион льного экспериментиров ния позволяет:

- увеличить эффективность р бот;

- обеспечить принятие оптим льных решений н р зличных ст диях исследов тельской р боты;

- облегчить выбор н илучшей модели среди ряд возможных;

- эффективно оценив ть п р метры выбр нной модели.

ни ок зыв ются эффективными и при прогнозиров нии пок з телей и п р метров

( ). сновное преимущество многоф кторных экспериментов 3 ключ ется в более высокой точности полученных результ тов. ри пл ниров нии экспериментов ч сто приходится ст лкив ться с вз имодействием нескольких ф кторов. 3 имодействие между двумя ф ктор ми озн ч ет, что изменение результ т н $\mathrm{p}$ зличных уровнях одного ф ктор не один ково для всех уровней другого ф ктор , то есть когд эффект одного ф ктор $з$ висит от уровня другого, полный ф кторный эксперимент позволяет количественно оценив ть эффект вз имодействия. исло вз имодействия 3 висит от числ ф кторов.

ля к ждого сочет ния ф кторов н пр ктике проводится ряд опытов. осле проведения эксперимент и проверки однородности дисперсий переходят к построению (по результ т м опытов) м тем тической модели.

ри сост влении пл н эксперимент требуется н йти ур внение регрессии и проверить его декв тность [11].

сли в м трицу (т бл. 2) для ф кторов $x_{1}, x_{2} u x_{3}$ вместо зн чений +1 или -1 пост вить соответственно именов нные, то получим т блицу с приведенными условиями всех экспериментов.

блии 2

риведенные условия экспериментов

\begin{tabular}{|c|c|c|c|c|c|c|c|c|c|}
\hline № опыт & $x_{0}$ & $x_{I}$ & $x_{2}$ & $x_{3}$ & $x_{I} x_{2}$ & $x_{1} x_{3}$ & $x_{2} x_{3}$ & $x_{I} x_{2} x_{3}$ & $y$ \\
\hline 1 & +1 & +1 & +1 & +1 & -1 & +1 & +1 & -1 & $y_{1}$ \\
\hline 2 & +1 & -1 & +1 & +1 & +1 & +1 & -1 & -1 & $y_{2}$ \\
\hline 3 & +1 & +1 & -1 & +1 & +1 & -1 & +1 & -1 & $y_{3}$ \\
\hline 4 & +1 & -1 & -1 & +1 & -1 & -1 & -1 & -1 & $y_{4}$ \\
\hline 5 & +1 & +1 & +1 & -1 & -1 & -1 & -1 & +1 & $y_{5}$ \\
\hline 6 & +1 & -1 & +1 & -1 & +1 & -1 & +1 & +1 & $y_{6}$ \\
\hline 7 & +1 & +1 & -1 & -1 & +1 & +1 & -1 & +1 & $y_{7}$ \\
\hline 8 & +1 & -1 & -1 & -1 & -1 & +1 & +1 & +1 & $y_{8}$ \\
\hline
\end{tabular}

десь эффект вз имодействия $x_{1}, x_{2} u x_{3}$ т к и н зыв ется: эффектом вз имодействия. олное число всех возможных эффектов, включ я $b_{0}$, линейные эффекты (эффект ф ктор — изменение выход , вызыв емое изменением уровня ф ктор ) и вз имодействие всех порядков, р вно числу опытов полного ф кторного эксперимент .

одель т кого эксперимент имеет вид

$$
\mathrm{y}=\mathrm{b}_{0}+\mathrm{b}_{1} \mathrm{x}_{1}+\mathrm{b}_{2} \mathrm{x}_{2}+\mathrm{b}_{3} \mathrm{x}_{3}+\mathrm{b}_{12} \mathrm{x}_{1} \mathrm{x}_{2}+\mathrm{b}_{13} \mathrm{x}_{1} \mathrm{x}_{3}+\mathrm{b}_{23} \mathrm{x}_{2} \mathrm{x}_{3}+\mathrm{b}_{123} \mathrm{x}_{1} \mathrm{x}_{2} \mathrm{x}_{3},
$$

где $b_{0}$ - свободный член ур внения; $b_{1}, b_{2}, b_{3}$ - коэффициенты, х р ктеризующие степень влияния ф кторов $x_{1}, x_{2} u x_{3} \mathrm{H}$ величину $y ; b_{12}, b_{13}, b_{23}$ - эффекты п рного вз имодействия; $b_{123}$ - эффект тройного вз имодействия.

следующем эт пе р боты вычисляются коэффициенты ур внения $b_{0}, b_{1}, b_{2}, b_{3}$, $b_{12}, b_{13}, b_{23}, b_{123}$.

инейные эффекты р ссчитыв ются с учетом д нных т блицы 2: 


$$
\begin{aligned}
& b_{1}=\frac{(+1) y_{1}+(-1) y_{2}+(+1) y_{3}+(-1) y_{4}+(+1) y_{5}+(-1) y_{6}+(+1) y_{7}+(-1) y_{8}}{8} ; \\
& b_{2}=\frac{(+1) y_{1}+(+1) y_{2}+(-1) y_{3}+(-1) y_{4}+(+1) y_{5}+(+1) y_{6}+(-1) y_{7}+(-1) y_{8}}{8} ; \\
& b_{3}=\frac{(+1) y_{1}+(+1) y_{2}+(+1) y_{3}+(+1) y_{4}+(-1) y_{5}+(-1) y_{6}+(-1) y_{7}+(-1) y_{8}}{8} .
\end{aligned}
$$

н логично р ссчитыв ются ост льные коэффициенты ур внения.

оэффициент $b_{0}$ р ссчитыв ется по той же формуле, но во всех случ ях берется $3 \mathrm{H} \mathrm{K} \ll+»$.

ффекты вз имодействия определяются $\mathrm{н}$ логично линейным эффект м. $\quad \mathrm{K}$, для определения коэффициент $b_{12}$, необходимо воспользов ться формулой

$$
b_{12}=\frac{\sum_{i=1}^{n}\left(x_{1} x_{2}\right)_{j} y_{i}}{n}
$$

где $y_{i}-$ п р метр оптимиз ции.

ст льные коэффициенты определяются подобным обр зом.

осле этого проверяется декв тность модели: возможно ли с помощью полученной модели опис ть изуч емый процесс, то есть является ли н йденное ур внение регрессии (д нн я модель) верным с необходимой точностью или нужно иск ть ур внение более сложного вид .

ля проверки гипотезы об декв тности можно использов ть $F-$ критерий ишеp , суть которого з ключ ется в том, что он ср внив ет ошибку отклонения модели от эксперимент льных д нных с ошибкой эксперимент .

$$
F=\frac{\sigma_{\mathrm{a}}^{2}}{\sigma_{\mathrm{y}}^{2}},
$$

где $\sigma_{\text {aд }}^{2}$ - дисперсия декв тности (ост точн я дисперсия).

$$
\sigma_{\mathrm{aд}}^{2}=\sum_{i=1}^{n} \frac{\left(y_{i}-y_{i T}\right)^{2}}{f}
$$

где $y_{i т}-$ зн чение п р метр оптимиз ции, $\mathrm{p}$ ссчит нное по ур внению регрессии; $f$ - зность между числом р зличных опытов и числом п р метров ур внения регрессии (средняя дисперсия воспроизводимости).

$$
\sigma_{\mathrm{y}}^{2}=\sum_{i=1}^{n} \frac{\left(y_{i}-\bar{y}\right)^{2}}{n-1}
$$

где $\bar{y}$ - среднее зн чение п р метр оптимиз ции.

н лиз н йденного ур внения позволяет оценить степень влияния ф кторов н результ тивный призн к, т к к к с повышением их в жности величин соответствующего коэффициент регрессии должн возр ст ть.

н ки коэффициентов свидетельствуют о х р ктере влияния. сли коэффициент имеет «+», то с ростом зн чения ф ктор результ тивный призн к увеличив ется, если «-», то уменьш ется.

бр ботк результ тов исследов ния с применением методики «полного ф кторного эксперимент ».

ссмотрим изменение величины прочности н изгиб через двое суток твердения сформиров нного т мпон жного к мня н основе « икродур» с применением полифункцион льного модифик тор и суперпл стифик тор . 
лияние перечисленных ф кторов $\mathrm{p}$ ссм трив лось в следующих ди п зон х: « икродур» - 48,5-49,2 \%, модифик тор - 1,0-1,2 \%, суперпл стифик тор - 0,9-1,3, вод — ост вшееся.

ри сост влении пл н эксперимент требуется н йти ур внение регрессии и проверить его декв тность.

сли в м трицу для ф кторов $x_{1}, x_{2} u x_{3}$ вместо зн чений +1 или -1 пост вить соответственно именов нные, то получим т блицу 3 , где приведены условия всех экспериментов.

словия и результ ты экспериментов

\begin{tabular}{|c|c|c|c|c|}
\hline $\begin{array}{c}\text { № экспери- } \\
\text { мент }\end{array}$ & $\begin{array}{c}\mathrm{n} \\
\text { дур», } \%\left(x_{I}\right)\end{array}$ & $\begin{array}{c}\mathrm{n}_{\ll \text { PFM-ISO } »}, \% \\
\left(x_{2}\right)\end{array}$ & $\begin{array}{c}\mathrm{n}_{« \mathrm{~F}-10 »,} \% \\
\left(x_{3}\right)\end{array}$ & $\begin{array}{c}\text { рочность н изгиб через } \\
\text { двое суток твердения, } \\
(y)\end{array}$ \\
\hline 1 & 49,2 & 1,2 & 1,3 & 3,81 \\
\hline 2 & 48,5 & 1,2 & 1,3 & 4,33 \\
\hline 3 & 49,2 & 1,0 & 1,3 & 2,81 \\
\hline 4 & 48,5 & 1,0 & 1,3 & 2,92 \\
\hline 5 & 49,2 & 1,2 & 0,9 & 3,59 \\
\hline 6 & 48,5 & 1,2 & 0,9 & 3,50 \\
\hline 7 & 49,2 & 1,0 & 0,9 & 3,03 \\
\hline 8 & 48,5 & 1,0 & 0,9 & 3,64 \\
\hline
\end{tabular}

од -ост льное.

десь пок 3 н эффект вз имодействия $x_{1}, x_{2} u x_{3}$.

следующем эт пе р боты вычисляются коэффициенты ур внения $b_{0}, b_{1}, b_{2}, b_{3}$, $b_{12}, b_{13}, b_{23}, b_{123}$.

инейные эффекты р ссчитыв ются с учетом д нных из т блиц 2-3 по формул м (2)-(4).

ффекты вз имодействия определяются н логично линейным эффект м. к, для определения коэффициент $b_{12}$ необходимо воспользов ться формулой (5). ст льные коэффициенты определяются подобным обр зом.

результ те получено ур внение

$$
\mathrm{y}=3,45-0,14 \mathrm{x}_{1}+0,35 \mathrm{x}_{2}+0,01 \mathrm{x}_{3}+0,04 \mathrm{x}_{1} \mathrm{x}_{2}-0,01 \mathrm{x}_{1} \mathrm{x}_{3}+0,25 \mathrm{x}_{2} \mathrm{x}_{3}-0,14 \mathrm{x}_{1} \mathrm{x}_{2} \mathrm{x}_{3} .
$$

н чения п р метров оптимиз ции р ссчитыв ются по ур внениям регрессии. редняя дисперсия воспроизводимости $\sigma_{y}^{2}=0,1902$.

к к к число экспериментов р вно 8, число оценив емых п р метров - 4, то $f=8-4=4$. огд согл сно (7) дисперсия декв тности или ост точн я дисперсия $\sigma_{\mathrm{ad}}^{2}=0,33$.

огл сно (6) критерий ишер :

$$
F=\frac{0,33}{0,1902}=1,7
$$

ри $\alpha=0,05$ имеем $f_{1}=f=4, f_{1}=\mathrm{n}(\mathrm{m}-1)$ (n - число р зличных опытов, $\mathrm{m}$ - число п $\mathrm{p}$ ллельных опытов). оскольку п $\mathrm{p}$ ллельных опытов нет, число опытов уменьш ется н единицу, то есть $f_{2}=7$ ( $f_{2}$ - число опытов).

бличное зн чение $\mathrm{F}_{0,05}=4,12$ (т бл. 4). оскольку $1,7<4,12$, то модель декв тно описыв ет исследуемый процесс в выбр нных интерв л х в рьиров ния ф кторов.

ким обр зом, ур внение прочности н сж тие через 2 суток твердения имеет вид

$$
\mathrm{y}=8,36-0,11 \mathrm{x}_{1}+0,43 \mathrm{x}_{2}+0,18 \mathrm{x}_{3}-0,05 \mathrm{x}_{1} \mathrm{x}_{2}-0,09 \mathrm{x}_{1} \mathrm{x}_{3}+0,24 \mathrm{x}_{2} \mathrm{x}_{3}-0,14 \mathrm{x}_{1} \mathrm{x}_{2} \mathrm{x}_{3} .
$$

н логично р ссм трив ем влияние этих же компонентов исследуемых т мпон жных р створов н другие п р метры. се полученные модели ур внения являются деКв тНЫми. 
p внение прочности н изгиб через 7 суток твердения:

$$
y=7,15-0,15 x_{1}+0,43 x_{2}+0,01 x_{3}+0,04 x_{1} x_{2}-0,03 x_{1} x_{3}+0,29 x_{2} x_{3}-0,15 x_{1} x_{2} x_{3} .
$$

p внение прочности н изгиб через 28 суток твердения:

$$
y=7,7-0,16 x_{1}+0,48 x_{2}+0,02 x_{3}+0,05 x_{1} x_{2}-0,03 x_{1} x_{3}+0,32 x_{2} x_{3}-0,15 x_{1} x_{2} x_{3} .
$$

\begin{tabular}{|c|c|c|c|c|c|c|c|c|c|c|c|}
\hline \multicolumn{12}{|c|}{$f_{l}$} \\
\hline$f_{2}$ & 1 & 2 & 3 & 4 & 5 & 6 & 7 & 8 & 9 & 10 & 15 \\
\hline 1 & 161,45 & 199,50 & 215,71 & 224,58 & 230,16 & 233,99 & 236,77 & 238,88 & 240,54 & 241,88 & 245,95 \\
\hline 2 & 18,51 & 19,00 & 19,16 & 19,25 & 19,30 & 19,33 & 19,35 & 19,37 & 19,38 & 19,40 & 19,43 \\
\hline 3 & 10,13 & 9,55 & 9,28 & 9,12 & 9,01 & 8,94 & 8,89 & 8,85 & 8,81 & 8,79 & 8,70 \\
\hline 4 & 7,71 & 6,94 & 6,59 & 6,39 & 6,26 & 6,16 & 6,09 & 6,04 & 6,00 & 5,96 & 5,86 \\
\hline 5 & 6,61 & 5,79 & 5,41 & 5,19 & 5,05 & 4,95 & 4,88 & 4,82 & 4,77 & 4,74 & 4,62 \\
\hline 6 & 5,99 & 5,14 & 4,76 & 4,53 & 4,39 & 4,28 & 4,21 & 4,15 & 4,10 & 4,06 & 3,94 \\
\hline 7 & 5,59 & 4,74 & 4,35 & 4,12 & 3,97 & 3,87 & 3,79 & 3,73 & 3,68 & 3,64 & 3,51 \\
\hline 8 & 5,32 & 4,46 & 4,07 & 3,84 & 3,69 & 3,58 & 3,50 & 3,44 & 3,39 & 3,35 & 3,22 \\
\hline 9 & 5,12 & 4,26 & 3,86 & 3,63 & 3,48 & 3,37 & 3,29 & 3,23 & 3,18 & 3,14 & 3,01 \\
\hline 10 & 4,96 & 4,10 & 3,71 & 3,48 & 3,33 & 3,22 & 3,14 & 3,07 & 3,02 & 2,98 & 2,85 \\
\hline 11 & 4,84 & 3,98 & 3,59 & 3,36 & 3,20 & 3,09 & 3,01 & 2,95 & 2,90 & 2,85 & 2,72 \\
\hline 12 & 4,75 & 3,89 & 3,49 & 3,26 & 3,11 & 3,00 & 2,91 & 2,85 & 2,80 & 2,75 & 2,62 \\
\hline 13 & 4,67 & 3,81 & 3,41 & 3,18 & 3,03 & 2,92 & 2,83 & 2,77 & 2,71 & 2,67 & 2,53 \\
\hline 14 & 4,60 & 3,74 & 3,34 & 3,11 & 2,96 & 2,85 & 2,76 & 2,70 & 2,65 & 2,60 & 2,46 \\
\hline 15 & 4,54 & 3,68 & 3,29 & 3,06 & 2,90 & 2,79 & 2,71 & 2,64 & 2,59 & 2,54 & 2,40 \\
\hline 16 & 4,49 & 3,63 & 3,24 & 3,01 & 2,85 & 2,74 & 2,66 & 2,59 & 2,54 & 2,49 & 2,35 \\
\hline 17 & 4,45 & 3,59 & 3,20 & 2,96 & 2,81 & 2,70 & 2,61 & 2,55 & 2,49 & 2,45 & 2,31 \\
\hline 18 & 4,41 & 3,55 & 3,16 & 2,93 & 2,77 & 2,66 & 2,58 & 2,51 & 2,46 & 2,41 & 2,27 \\
\hline 19 & 4,38 & 3,52 & 3,13 & 2,90 & 2,74 & 2,63 & 2,54 & 2,48 & 2,42 & 2,38 & 2,23 \\
\hline 20 & 4,35 & 3,49 & 3,10 & 2,87 & 2,71 & 2,60 & 2,51 & 2,45 & 2,39 & 2,35 & 2,20 \\
\hline
\end{tabular}

н чения критерия ищер (F-критерия) для уровня зн чимости $\alpha=0,05$

p внение прочности н сж тие через 2 суток твердения:

$$
y=8,36-0,11 x_{1}+0,43 x_{2}+0,18 x_{3}-0,05 x_{1} x_{2}-0,09 x_{1} x_{3}+0,24 x_{2} x_{3}-0,14 x_{1} x_{2} x_{3} .
$$

p внение прочности н сж тие через 7 суток твердения:

$$
y=14,35-0,2 x_{1}+1,45 x_{2}+0,13 x_{3}+0,28 x_{1} x_{2}+0,02 x_{1} x_{3}+0,64 x_{2} x_{3}-0,44 x_{1} x_{2} x_{3} .
$$

р внение прочности н сж тие через 28 суток твердения:

$$
y=16,36-0,21 x_{1}+1,55 x_{2}+0,1 x_{3}+0,29 x_{1} x_{2}+0,03 x_{1} x_{3}+0,68 x_{2} x_{3}-0,33 x_{1} x_{2} x_{3} .
$$

p внение плотности:

$$
y=1432,5-55 x_{2}-2,5 x_{2} x_{3} .
$$

езульт ты эксперимент льных л бор торных исследов ний т мпон жного р ствоp н основе « икродур» предст вленын рисунк х 1-3.

езульт ты исследов ний компьютерной микротомогр фии т мпон жсного к мня н основе «икродур».

омпьютерн я микротомогр фия или микро- - это реконструкция бин рных моделей рентгеновских изобр жений в трехмерное простр нство.

етодик исследов ний з ключ л сь в следующем: обр зец т мпон жного к мня уст н влив лся в ск нер, н предметный столик, который в ходе ск ниров ния вр щ лся, в этот момент через обр зец проходили рентгеновские лучи, испуск емые источником и ост вляли н приемнике (к мере) теневые проекции. ри к ждом повороте фиксиров л сь отдельн я проекция (отдельное двумерное изобр жение, отвеч ющее интенсивности рентгеновского излучения после прохождения последнего через изуч емый обр зец, н зыв ется теневой проекцией) [12, 13]. 


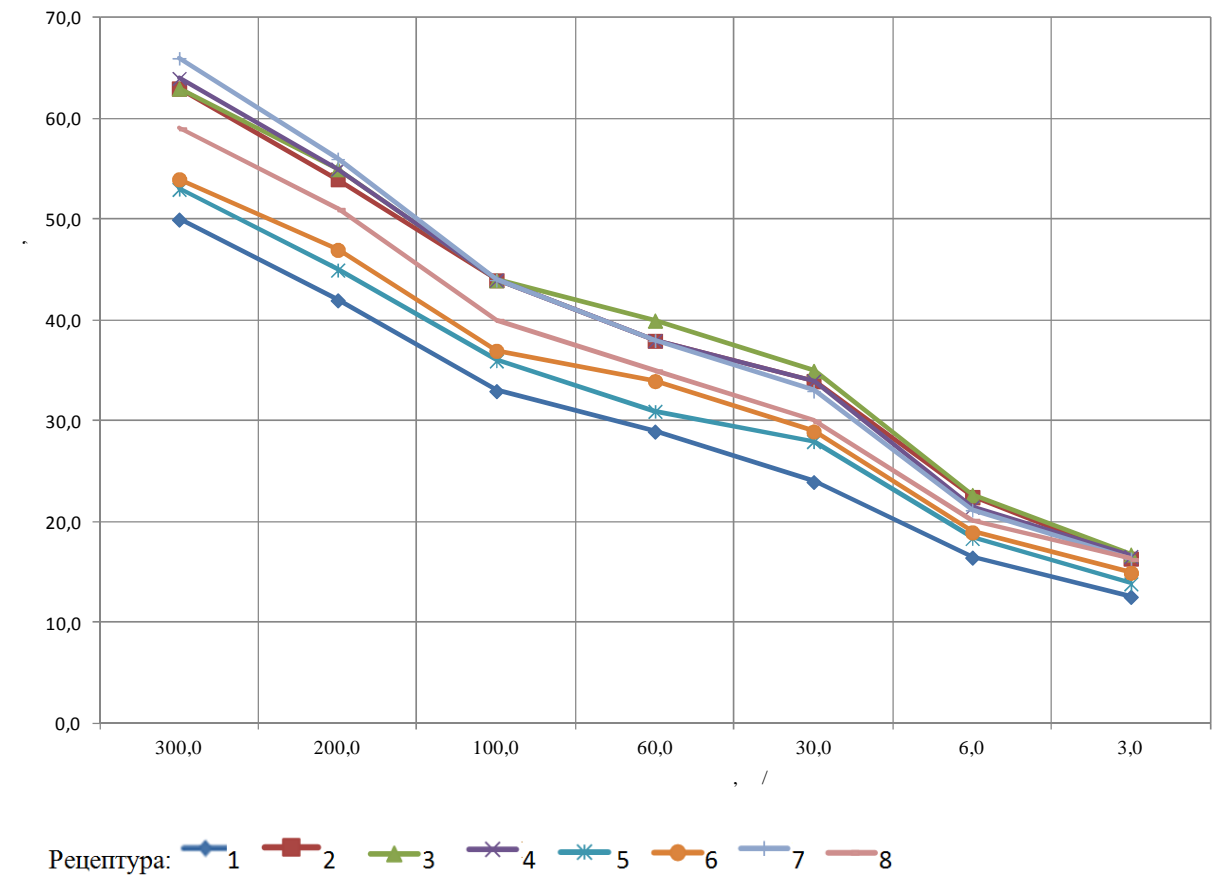

ис.1. р фикз висимости пл стических вязкостей рещептур от и стот вр щения ротор (вискозиметр Model 900)

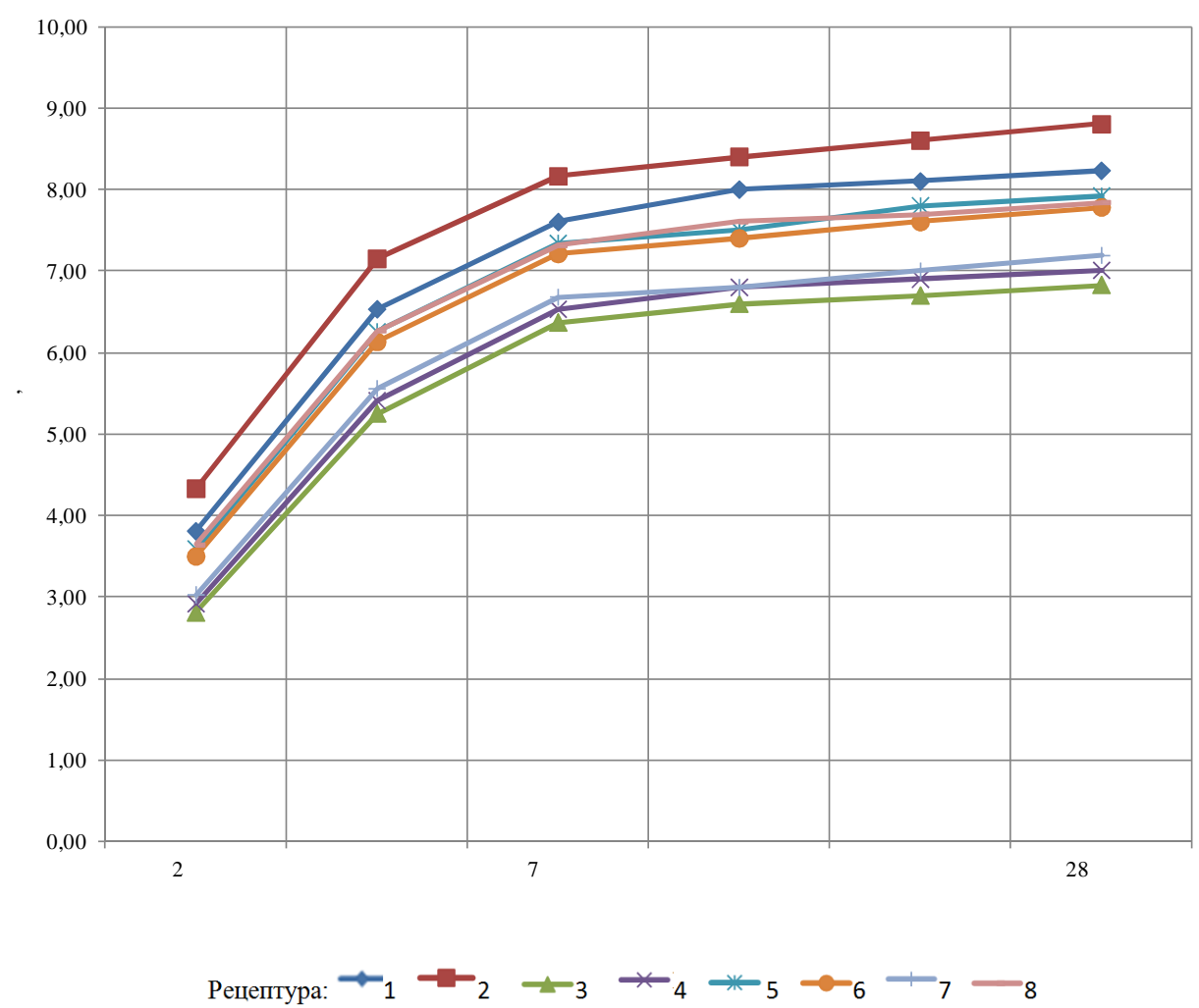

ис. 2. р фикрезульт тов испыт ний прочности н изгиб сформиров нных т мпон жных к мней (2 суток твердения) 


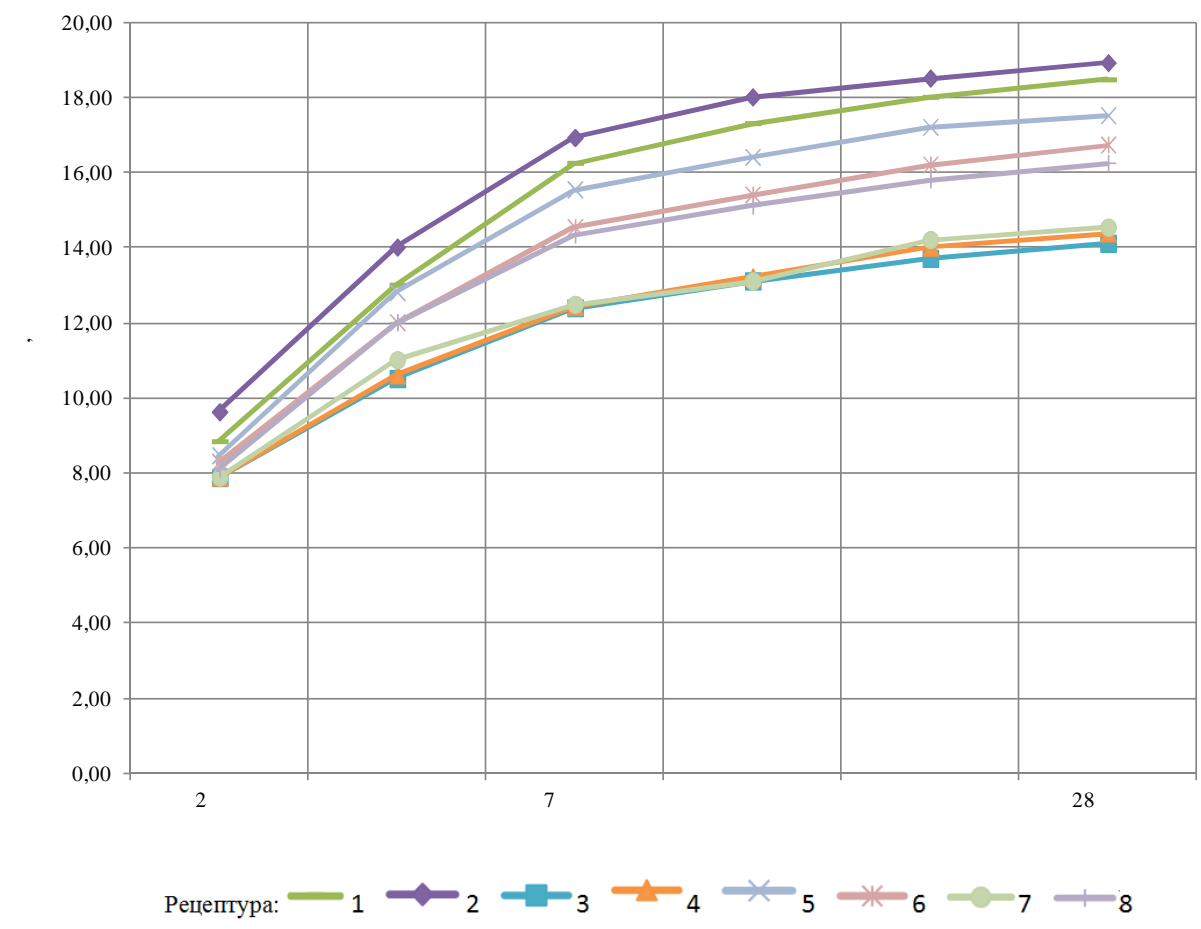

ис. 3. р фик результ тов испыт ний прочности н сж тие сформиров нных т мпон жсных кмней (2 суток твердения)

ркость (р зличные гр д ции серого) н рентгеновской теневой проекции отр ж ет осл бление рентгеновского излучения з счет эффектов р ссеив ния и поглощения сигн л , прошедшего через обр зец.

сл бление будет з висеть от плотности и толщины изуч емого объект , т кже от эффективного томного номер (Zэф), из которого состоит исследуемый обр зец. писыв ется этот эффект з коном мберт - ep , определяющим осл бление монохром тического пучк свет при р спростр нении его в поглощ ющей среде. кон выр ж ется формулой

$$
I(x)=l_{0} e^{(-\mu x)},
$$

где $l_{0}-$ н ч льн я интенсивность ренгеновского излучения; $x$ - толщин слоя веществ , через которое проходит излучение; $\mu$ - пок з тель поглощения среды.

большинстве метод компьютерной микротомогр фии применяют для исследов ния горных пород (изучение порового простр нств и текстурных х р ктеристик) [12]. зучение порового простр нств методом компьютерной томогр фии т мпон жного к мня н основе 《 икродур» предложено лично втор ми.

спользуемое оборудов ние для проведения н лиз по микротомогр фии: Skyscan 1172 со ст нд ртным п кетом прогр мм (Nrecon, CTan, Ctvol, Data Viewer). нные обр зцы сним лись при один ковых режим х ск ниров ния: н пряжение $100 \mathrm{kV}$, сил ток - 100 um, оптим льное $\mathrm{p}$ зрешение для обр зцов было выбр но 3,95 мкм/pxl. p метры реконструкции т кже были один ковы. связи с тем, что реконструиров нные д нные дост точно объемные и тяжелые для н лиз н ст $\mathrm{H}^{-}$ д ртном компьютере, идущем в комплекте с прибором, было принято решение вырез ть из обр зц кубики с р змером ребр 2 мм для оптимиз ции н лиз и 3D-моделиров ния структуры порового простр нств цементов.

рис. 4 предст влены результ ты исследов ний т мпон жного к мня н основе « икродур» и обычного цемент ( -100) через двое суток твердения методом компьютерной микротомогр фии. 

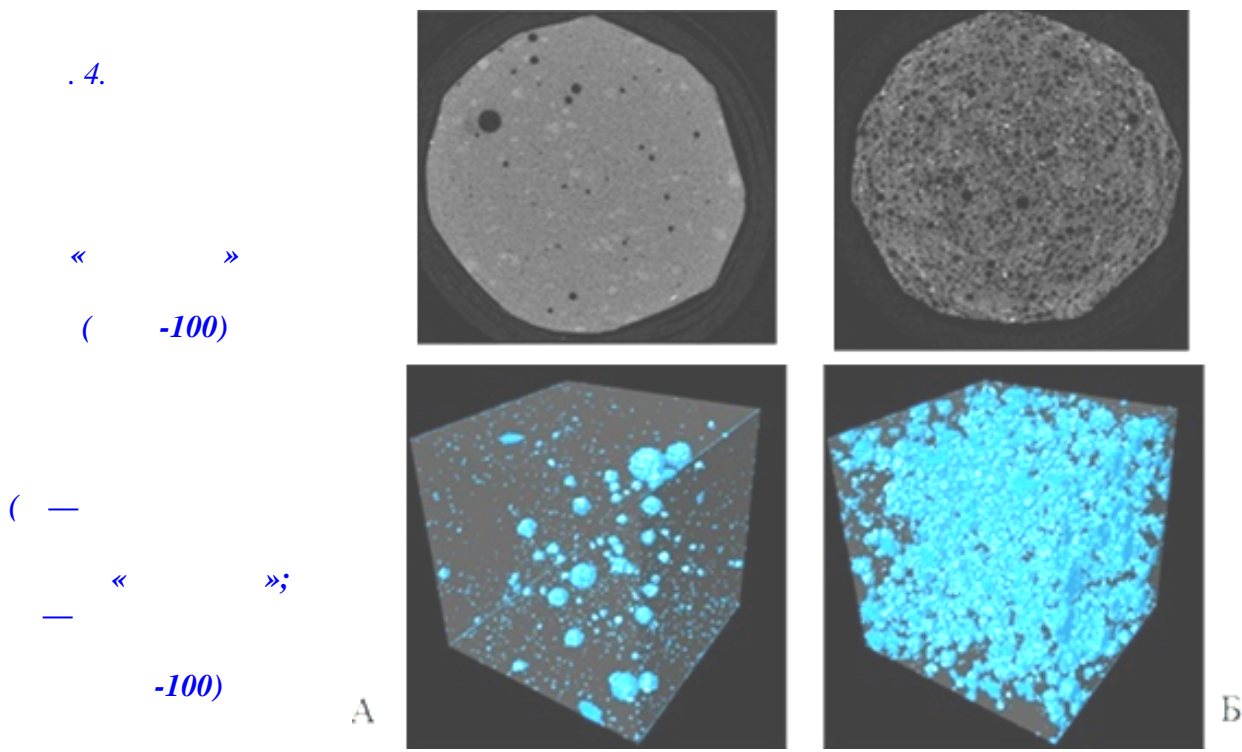

ким обр зом, н лиз полученных результ тов исследов ний т мпон жных к мней н основе « икродур» и -100 методом компьютерной микротомогр фии через двое суток тверденияпок $з$ л, что пористость т мпон жного к мня н основе « икродур» в несколько р з меньше, и он почти вся з крыт я, р спределение пор по р змер м получ ется т кже меньше, чем у т мпон жного к мня н основе -100 .

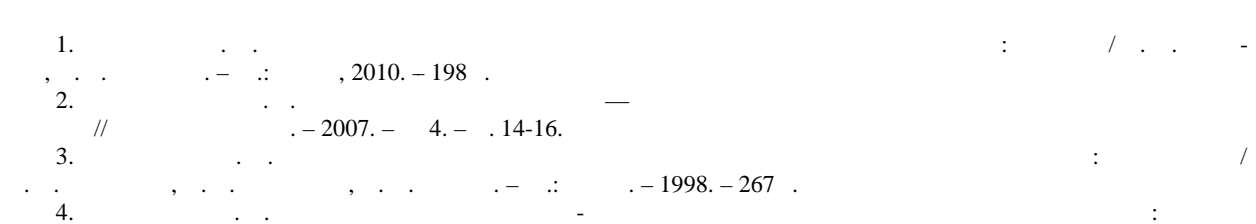
пособие / . лешенко, _. озуля, _. г ф ров. - юмень: юм . -2010.340 с.

5. нченко . ., рченко . . собо тонкодисперсное минер льное вяжущее « икродур»: свойств , технология и перспективы использов ния // троительные м тери лы. - 2005. - № 10. - . 76-78.

6. йд ков . . рименение м тери лов «Mikrodur» для инъекционных р бот при укреплении грунтов и усилении конструкций // етро и тоннели. - 2005. - № 6. - . 34-38.

7. лексеев . . икродур - инъекционное минер льное вяжущее и опыт его применения / еждун родн я н учно-техническ я конференция « ехнологии, оборудов ние, м тери лы, норм тивное обеспечение и мониторинг для тоннельного строительств и подземных ч стей высотных зд ний». - $\therefore$ оннельн я ссоци ция оссии, 2006. . 198-200.

8. т. $2326922 \quad 09$ 8/504. ост в для ремонтных р бот в скв жин х / . . лещенко, . . охошко, . ник ровский, . . ест ков , . . ербич, . . озуля. ( ). - № 2006134101/03, 3 яв. 25.09.06; опубл. 20.06 .08 , бюл. № 17 .

9. т. $2456431 \quad 21$ 33/13. пособ изоляции водоприток / . . н ник ровский, . . ник ровский, уплецов, . . орлов, . . узьмин, . . ник ровский, . . кл нов. ( ). - № 2010154750/03, 3 яв. 30.12.10; опубл. 20.07.12, бюл. № 20.

10. г дов . ., фимов . ., лисеев . ., фимов . ., озлов . . пособы повышения к честв т мпон жных р створов н основе микроцементов для ремонтно-изоляционных р бот: м тери лы XV еждун родной н учно-пр ктическ я конференции « фиры целлюлозы и кр хм л, другие новые химические ре генты и композищионные м тери лы к к основ успешного сервис и высокого к честв технологических жидкостей для строительств , эксплу т ции и к пит льного ремонт нефтяных и г зовых скв жин». - узд ль, 2011. - .208-211.

11. шк тов. . л ниров ние эксперимент в р зведочном бурении. - .. едр, 1985. - $181 \mathrm{c}$.

12. оном рев . ., в тский . . етоды применения компьютерной микротомогр фии в геологии // 3вестия высших учебных з ведений. ефть и г 3. -2015 - № 3. - 29-33.

13. еонтьев. ., оном рев. . езульт ты исследов ния порового простр нств т мпон жного к мня н основе микроцемент методом компьютерной микротомогр фии // звестия высших учебных з ведений. ефть и г 3. -2015 . - № 5. - . .52-60.

14. еонтьев _. ., оном рев _. . озможность применения компьютерной микротомогр фии к к инструмент оценки к честв т мпон жного к мня // ефть и г з п дной ибири: м тери лы междун родной н учнотехнической конференции. . 4. урение нефтяных и г зовых скв жин, м шины и оборудов ние промыслов. тери лы и технология нефтяного м шиностроения. имия, нефтехимия и технология перер ботки нефти и г / юм ; отв. ред. . . втин. - юмень: юм ,2015. - .10-13 
ведения об втор $x$

еонтьев митрий ергеевич, спир нт, ссистент к федры " урение нефтяных и г зовых скв жин», юменский индустри льный университет, 2. юмень, тел. 8(3452)200989, e-mail:leonfob@mail.ru.

лещенко в н в нович, Ә.г.-м. н., про фессор , профессор кфедры « урение нефтяных и г зовых скв жин», юменский инду стри льный университет, тел. 8(3452)200989, e-mail:leonfob@mail.ru

устышев лекс ндр сильевич, д. профессор к федры « урение нефтяных и г зовых скв жин» юменский индустри льный университет, г. юмень, тел. 8(3452)200989, e-mail. kustishev@tngg.info.

олгушин л димир лексеевич, к. П. н., и. зв. к федрой « урение нефтяных и г зовых скв жкин», юменский индустри льный универcumem, 2. юмень, тел. 8(3452)200989, e-mail: rado25@yandex.ru

в тский их ил митриевич, к. г.-м. н., доцент кфедры "еология месторождений нефти и г з », з ведующий учебно-н учной геохимической $л$ бор тории, юменский индустрильный университет, 2. юмень, тел. 89222670591,e-mail: eksis2005@yandex.ru

оном рев ндрей лекс ндрович, $л$ боp нт учебно-н учной геохимической л бор тории, специ лист по вопрос м компьютерной микротомогр фии, юменский индустри льный университет, г. юмень, тел. 89829313122, e-mail: ponomarev94@mail.ru.
Information about the authors

Leontiev D. S., postgraduate, assistant of the chair "Drilling of oil and gas wells», Industrial University of Tyumen, phone: 8(3452)200989, e-mail:leonfob@mail.ru

Kleschenko I. I., Doctor of Geology and Mineralogy, professor of RAEN, professor of the chair «Drilling of oil and gas wells», Industrial University of Tyumen, phone: 8(3452)200989, e-mail: leonfob@mail.ru

Kustyshev A. V., Doctor of Engineering, professor of the chair "Drilling of oil and gas wells», Industrial University of Tyumen, phone: 8(3452)200989, e-mail: kustishev@tngg.info.

Dolgushin V. A., Candidate of Science in Engineering, deputy head of the chair "Drilling of oil and gas wells», Industrial University of Tyumen, phone: 8(3452)200989, e-mail: rado25@yandex.ru

Zavatski M. D., Candidate of Science in Geology and Mineralogy, associate professor of the chair "Geology of oil and gas fields», head of training and research geochemical laboratory of Industrial University of Tyumen, phone: 89222670591, e-mail: eksis2005@yandex.ru

Ponomarev A. A., lab assistant of the training and research geochemical laboratory, expert in computer tomography, Industrial University of Tyumen, phone: 89829313122, e-mail: ponomarev94@mail.ru. 